\title{
The Effect of Alternative Market Orientation Strategies on Firm Performance
}

\author{
Eric T. Micheels (Corresponding author) \\ Assisstant Professor, Department of Bioresource Policy, Business \& Economics \\ University of Saskatchewan, Canada \\ E-mail: etm550@mail.usask.ca \\ Hamish Gow \\ Professor of Agribusiness, College of Business, Massey University, New Zealand \\ E-mail: h.r.gow@massey.ac.nz
}

Received: February 6, 2012 Accepted: March 6, 2012 Published: June 1, 2012

doi:10.5539/ijms.v4n3p2 URL: http://dx.doi.org/10.5539/ijms.v4n3p2

\begin{abstract}
Research studies have differed over the importance of the relative emphasis of a customer versus competitor orientation in the development of a market orientation (Slater \& Narver, 1994; Tajeddini, 2010). In this study, we assess whether the emphasis of one component over another of a market orientation is an important determinant of firm performance within the Illinois beef industry, specifically the cow-calf sector. Using a series of OLS regressions, we examine the importance of a market orientation, relative emphasis, learning, innovativeness, and a cost focus on firm performance in a sample of 269 beef farms. Our results suggest that firms should invest equally in awareness of both customer demands and competitor responses as opposed to a singular focus on one or the other. This result corroborates the findings of Slater and Narver (1994), while examining the relationship within a highly competitive, homogeneous market. Implications and directions for future research are also discussed.
\end{abstract}

Keywords: Agriculture, Innovation, Market orientation, Relative emphasis, Value discipline strategies

\section{Introduction}

It has been suggested that firm performance is a function of market structure and the behavior of firms within the competitive landscape. Schumacher and Boland (2005) find that firm performance is largely dictated by industry choice while characteristics of the firm are important for only the best firms in a given industry. Within the context of agriculture, many commodity markets resemble perfectly competitive markets with homogeneous products and low barriers to entry and exit. In homogeneous markets, producers often focus on improving production efficiency as they see this as their only means of improving financial performance. In environments where competition is based on the firm's ability to be the low-cost provider of undifferentiated goods and services, Porter (1985) posits sustained success will depend on cost drivers such as economies of size, capacity utilization, technology adoption and organizational learning. Within agricultural commodity markets, however, firms can find it difficult to achieve economies of size and scope. As a result, firms may find themselves unable to clearly articulate a strategy for competing in highly competitive markets.

Conversely, within differentiated markets, firms strive to deliver superior value by providing augmented products and services more efficiently than rivals. Competitive advantage within such markets is based on the firm's capability in the discovery and delivery of value added products that support a specific consumer experience. Firms achieving a differentiation advantage are those that are able to create positive difference between the value of the augmented product and the costs associated in delivering it. Within these markets superior value can be provided in several ways. Treacy and Wiersema (1993) quantified these methods into three singular value disciplines, operational excellence, product leadership and customer intimacy (Note 1). Combined with commodity production, direct marketing of farm production and producer alliances, it appears all three value disciplines are present in the agricultural context. 
Furthermore, it has been suggested that market oriented firms are better able to define their own value discipline, which allows them to allocate resources more efficiently and to focus on appropriate consumer segments (Narver, Slater, \& Tietje, 1998). Recently, Authors(2009) found that extreme levels of market orientation, along with organizational learning and innovation, led to increased value discipline clarity. Treacy and Wiersema (1993) posit that the choice of customers and value disciplines is simultaneous. That is, operationally excellent firms are likely going to have a hard time marketing their production to customers that value close relationships with suppliers and vice versa. If this suggestion is indeed the case, are the individual components of a market orientation equally important across value discipline strategies?

The objective of this study is to determine if the relative level of customer and competitor orientation affect firm performance across various value disciplines. Using a sample of Illinois beef producers, we empirically measure the farmer's choice of value discipline as well as their level of market orientation and relative emphasis on a customer or competitor orientation. While Slater and Narver (1994) have shown that a general market orientation is important determinant of firm performance in any business environment, this study will attempt to further define and clarify these findings. Specifically, we suggest that the means by which the market orientation resource is developed may affect firm performance across various value discipline strategies. If the ideas brought forward by Day and Wensley (1988) are correct, we hypothesize that the relative importance of customer and competitor orientation will differ based on the chosen value discipline of the firm.

\section{Literature Review}

Porter (1985) suggests that firms can provide superior value by being the low-cost producer of an undifferentiated product or by providing differentiated products more efficiently. Within agricultural livestock markets, specifically the cow-calf sector, many firms have sought to become the low-cost producer, often by striving to achieve economies of scale, with varying rates of success (Jones, 2000). Confounding the analysis is the fact that within the U.S. cow-calf sector, economies of scale were observed as herd sizes approach 250 head (Lamb \& Beshear, 1998), and while a majority of producers have herd sizes under this threshold, low cost producers were found among all size groups (Jones, 2000). Firms operating within such markets may find a market orientation to be a valuable resource in discovering market opportunities based on unexpressed needs or the failure of competitors to meet expressed needs, or both.

A market orientation is broadly defined as the culture of the firm which focuses on the creation of superior value for customers (Narver et al., 1998). Defining a market orientation within a behavioral context, Jaworski and Kohli (1993) identified several activities that are present within market oriented cultures, such as intelligence generation, intelligence dissemination, and finally the response to new information. Similarly, Narver and Slater (1990) suggest that a market orientation consists of three inter-related components, namely a customer orientation, a competitor orientation, and interfunctional coordination. Through behaviors within the respective orientations, firms seek to gather and disseminate pertinent market information relating to customer needs and competitor actions in the search for opportunities to provide superior value to the market. Firms with a highly developed market orientation may be able to discover opportunities before rivals and thus establish customer loyalty and market share which may improve firm performance. Across a variety of markets and cultures, a market orientation has been found to be an important driver of firm performance (Hinson \& Abdulai, 2011; Hult \& Ketchen, Jr., 2001; Johnson, Dibrell, \& Hansen, 2009; Mokhtar, Yusoff, \& Arshad, 2009).

Within segmented and fragmented markets, Pelham $(1997,1999)$ found a market orientation was a significant contributor to superior firm performance. In commodity markets, however, the results regarding the importance of a market orientation in determining firm performance have thus far been mixed(see Narver \& Slater, 1990; Pelham, 1997; Verhees \& Meulenberg, 2004). While a market orientation may be an important resource for all firms regardless of competitive environment and competitive hostility (Slater \& Narver, 1994), the relative emphasis of customer versus competitor orientation may be equally important depending on the choice of value discipline.

The relative emphasis on customers or competitors has been tested across a variety of industries and cultures with mixed results. Slater and Narver (1994)examined the importance of a market orientation and the relative emphasis using a sample of strategic business units (SBUs) in a forest products firm and a diversified manufacturing firm and found that a market orientation was a significant driver of performance, but relative importance was not significant, even when accounting for competitive intensity, buyer power, and market growth. The results from Slater and Narver (1994) would suggest that there is no benefit to being relatively more competitor or customer oriented; a market orientation is an important determinant of firm performance and changing the emphasis given market conditions may not be prudent. However, the results from Slater and Narver 
(1994) were observed using data from various SBUs of only two firms. This fact certainly limits the confidence researchers have in any generalizations that can be drawn from this research.

To that end, several published research reports have examined the importance of the relative emphasis of customer and competitor orientation within a market orientation across a wider spectrum of industries and settings. Using data from a sample of 393 marketing executives from a wide range of U.S. businesses, Gatignon and Xuereb (1997) found evidence to suggest for firms operating within uncertain markets a customer orientation may provide greater returns than would a competitor orientation and vice versa.

Furthermore, results from the hotel industry suggest that a customer orientation is an important determinant of firm performance (Dev, Zhou, Brown, \& Agarwal, 2009; Tajeddini, 2010). Lukas and Ferrell (2000) further suggest that the relative emphasis on customer (competitor) orientation leads to greater (less) innovativeness. Firms that are more acutely aware of unarticulated needs may be better positioned to develop more radical innovations as opposed to the incremental innovations which are developed following awareness of articulated needs.

Narver and Slater's (1990) description of a market orientation as a one-dimensional theoretical construct consisting of three behavioral components (customer orientation, competitor orientation and coordination) suggests that each component is equally important in determining firm performance. Some scholars have suggested this may not always be the case(Lukas \& Ferrell, 2000). Day and Wensley (1988) posit that firms operating under different strategies (low-cost, differentiation) would likely develop different resources to succeed within their chosen strategy. Therefore, when developing a market orientation, should firms develop a customer orientation at the same rate as they develop their competitor orientation? The answer to this question likely depends on their choice of value discipline.

\section{Testable Hypothesis}

\subsection{Market Orientation}

Market oriented firms are thought to achieve superior performance vis-à-vis their less market oriented rivals as a market orientation allows the firm to become aware of opportunities to provide superior value to consumers. As a firm discovers consumers' latent needs and translates this knowledge into new products, performance measures should improve as revenues increase due to premium prices and/or increased sales. In either commodity or non-commodity channels, higher beef prices can be earned by providing downstream users with the specific product attributes they value. A market orientation has been found to be a significant driver of firm performance across a variety of industries and cultures (Deshpandé, Farley, \& Webster, 1993; Narver \& Slater, 1990; Verhees \& Meulenberg, 2004).

Slater and Narver (1994) found a statistically significant relationship between market orientation and performance in their research on several SBU's of a forest product firm, even when accounting for competition. Similar results displaying the performance implications were found in several business environments including large UK firms (Greenley, 1995), small to medium sized enterprises in the UK food sector (Tregear, 2003) as well as in buyer-supplier relationships (Bigne \& Blesa, 2003).

H1a: An increase in the market orientation of the firm will lead to an increase in firm performance.

H1b: An increase in the market orientation of the firm will lead to an increase in firm performance for customer intimacy producers.

H1c: An increase in the market orientation of the firm will lead to an increase in firm performance for operational excellence producers.

\subsection{Relative Emphasis}

While a low-cost strategy is widely deployed in production agriculture systems, it does have its limitations. One major limitation is its lack of ex post barriers to competition (Peteraf, 1993). That is, the use of a low-cost strategy does not preclude other firms from employing the same strategy. Kim and Mauborgne (2004) deem these competitive environments 'red oceans' as many firms are competing based on similar strategies and a war of attrition ensues. Perhaps not surprisingly, strategy imitation has been shown to lead to mediocre performance for many firms (Porter, 1991; Teece, Pisano, \& Shuen, 1997). Perhaps as a result, an increasing number of innovative and entrepreneurial producers are forgoing the commodity route, and are instead attempting to produce a non-commodity product based on the various attributes demanded by heterogeneous consumers.

Within such segmented markets, the decision regarding how the firm actually chooses to provide value is especially important. Porter (1985) has posited that firms which fail to focus on one specific strategy, either 
low-cost provision or differentiation, risk becoming 'stuck in the middle' which can lead to mediocre performance vis-à-vis rivals with a clear vision of their value discipline. To be sure, the specific strategic choice would likely depend on the opportunities available to the firm as well as the specific resources and capabilities available internally and externally to the firm. Extending the work of Porter (1985), Treacy and Wiersema (1993) developed three value disciplines, operational excellence, customer intimacy, and product leadership, to explain different strategies firms can use to provide value for the consumer. Within an agricultural context, commodity producers may be better served by focusing on buyers or consumers as the sheer number of competitors puts a limit on the accuracy and the amount of competitor monitoring that can be conducted.

H2: An increase in the relative emphasis of a customer orientation will lead to an increase in firm performance for firms within a customer intimacy value discipline.

H3: An increase in the relative emphasis of a customer orientation will lead to a decrease in firm performance for firms within an operational excellence value discipline.

\subsection{Organizational Learning}

Using a survey of business executives of both large and small firms, Baker and Sinkula (1999) find support for a learning orientation to directly affect both innovation and firm performance. In the beef industry, we feel market sensing capabilities brought about by organizational learning would increase a firm's ability to innovate as well as increasing their market orientation while also allowing for an improved cost focus of the firm. Being efficient is a superior quality in many industries, but is of great importance for firms participating in commodity markets. In this case, firms operating in commodity marketing channels may increase their efficiency through their learning orientation.

H4: An increase in the firm's learning orientation will lead to an increase in firm performance.

\subsection{Innovativeness}

Market oriented firms are thought to gather information concerning consumer's current and future needs, but what happens following the gathering and dissemination of this information? Provided a firm has the capacity to innovate, it is likely this market information is transformed into product innovations to meet consumer needs. These innovations do not need to be frame-breaking, however. Increased communication with downstream partners would be considered an innovation if communication is not typical of the business relationship. While meeting a goal of the 2005 NBQA, increased channel communication can aid producers in modifying production practices or in altering the genetic make-up of the herd as a means of improving quality and efficiency.

In our study we conceptualize innovation as the willingness to use new ideas to improve the cattle operation, but leave what exactly that new idea is to the respondent. In this instance, the innovation could be a means of improving efficiency through a technological innovation or by improving the product offering though an externally focused innovation. In their study of a sector of the U.S. government, Hurley and Hult (1998) found innovation to be an important driver of performance. Similar results were found in studies using large Japanese firms (Deshpandé et al., 1993), U.S. banks (Han, Kim, \& Srivastava, 1998), and New Zealand firms (Darroch \& McNaughton, 2003). In all cases market knowledge was the primary driver of the innovation. Increased market knowledge allows firms to modify routines in a way that provides the consumer with the attributes which they desire.

\section{H5: An increase in the level of innovativeness will lead to an increase in firm performance.}

\subsection{Cost Focus}

A market orientation is an inherently external view of the current environment in which the manager operates. Market information is gathered, processed and implemented to modify routines in order to improve the product offering and, in turn, earn a premium price for doing so. However, it is still important to maintain a balance between the external and internal focus of the firm. In fact, once an innovation has caught on in the marketplace, the entrepreneurial rent from the innovation is likely to have already disappeared as increased competition has removed the premium price. Therefore, we also model the manager's cost focus as a determinant of firm profitability.

Featherstone, Langemeier and Ismet (1997) find increased efficiency in beef production is a necessary condition for high net income. Higher prices could be earned by producing products with desired attributes, but being able to efficiently provide an augmented product may be more important in the long-run. In some sectors of the beef industry, efficiency may be more important than a market orientation in the short-run, provided the market is stable and not undergoing rapid change. A producer operating in the commodity beef sector may still feel 
increasing efficiency is their only method of improving performance. Support for this mind-set is given in Narver and Slater's (1990) study of the commodity SBUs of the forest product firm they studied in their seminal article. They found performance to have a U-shaped relationship to the level of market orientation in the commodity SBUs; that is, on average an SBU with a low level of market orientation outperformed those with a medium level of market orientation.

H6: An increase in the cost focus of a firm will lead to an increase in firm performance for firms within the operational excellence value discipline.

H7: An increase in the cost focus of the firm will lead to a decrease in firm performance for firms within the customer intimacy value discipline.

\section{Data}

A mailing list consisting of the names and addresses of 1569 members of the Illinois Beef Association was used as the sample population. An initial wave of the survey was mailed out to half of the survey population in June 2007 with a reminder card following 2 weeks later. Four weeks after the initial mailing, a second survey was sent to non-respondents. Following the first wave of mailings, a total of 170 completed surveys were returned. In November 2007, the survey was sent to the second half of the mailing list in an attempt to increase the sample size. In total, 347, complete usable surveys were returned resulting in a $22.1 \%$ response rate (Note 2). As late respondents have been shown to be similar to non-respondents, the sample was tested for differences as outlined in Armstrong and Overton (1977). No significant differences were found between early and late respondents.

Before the survey was mailed, questions were examined by University of Illinois extension specialists to verify question clarity and scale relevance. Following slight rephrasing, the survey instrument was mailed to a small sample of Farm Business Farm Management Association (FBFM) cooperators to allow them to comment on question clarity and relevance. Following the instrument pilot testing, changes were made to the survey to improve the readability while also increasing the response rate relative to a less user-friendly survey. The survey instrument asked producers to determine their value discipline by allocating points among various phrases relating to production, pricing, relationships, and quality.

\subsection{Respondent Characteristics}

Table 1 provides some information about the demographic characteristics of the respondents, as well as other pertinent characteristics. The results presented here refer to the 269 cow-calf producers that participated in the 2007 survey of Illinois beef producers conducted by the authors. On average, the respondents are over 41 years of age, have greater than 16 years' experience in the beef industry and are highly educated.

Insert Table 1 here

\subsection{Measurement Scales}

Whenever possible, measurement scales were drawn from previously published research. A new scale was developed to measure value discipline clarity (Note 3). The concept of a firm's market orientation was measured using the scale first developed by Narver and Slater (1990). In this manner, a firm's market orientation is comprised of their customer and competitor focus as well as the coordination of market knowledge within the firm. As with all the measures we used, we modified the verbiage to fit with production agriculture and pre-tested the scales with extension personnel so construct meaning was not lost in translation. To measure organizational learning, four items from Farrell and Oczkowski (2002) were used. These items sought to measure the "learning culture" of the farm business. Innovativeness was measured using a scale tested by Hurley and Hult (1998), and measured the penchant for managers to utilize innovative strategies to solve problems on the farm. The final independent variable measures the cost focus of the firm. This was measured using a combination of scales developed by Homburg, Workman and Krohmer (1999) and Kotha and Vadlamani (1995). The scale measured the manager's focus on production efficiency and cost reduction as a means of improving performance.

The independent latent variables were used to measure subjective performance on beef farms in Illinois. Seven subjective performance indicators were included in this study to measure both the producers' satisfaction with individual and comparative performance. Respondents were asked, using a 6-point Likert scale, to rate their satisfaction with their return on assets, cash flow, production and marketing investments, and overall performance. To assess comparative performance, respondents were asked to rate the overall performance of the farm business as well as prices received relative to their competitors. Subjective performance was used as our sample consisted of small, privately held businesses which are generally unwilling to share confidential financial data, even in an anonymous setting. 


\subsection{Control Variables}

Age of operator, experience, and farm size were all included as control variables. Experience was measured as the number of years that the producer has been producing beef cattle. Farm size was indicated by the number of brood cows on the farm.

\subsection{Common Method Variance}

Single informants were used in this study, so some bias may be introduced due to "halo effects", which occur when indicators measuring dependent constructs are biased by the independent variables. However, this bias could not be eliminated as these firms are generally one-farmer operations. To check for common method variance, all variables used in the analysis examined using an unrotated factor analysis. If a significant amount of explained variance can be attributed to one factor, common method variance may be a problem. In the study, the combined factor analysis resulted in 11 factors with eigenvalues greater than 1.0 , which accounted for $65.71 \%$ of the variance. Factor one accounted for $20.70 \%$ of the explained variance, therefore common method variance is unlikely to be an issue with our data.

\section{Methodology}

\subsection{Construct Reliability}

Reliability is an important concept in the development of accurate and valid measurement scales. When testing for unobservable theoretical constructs, it is important that the scales reliably measure what they are intended to measure. The purified measurement scales along with their means, standard deviations, item-to-total correlations, factor loadings, extracted variances, and coefficient alphas are shown in Appendix A. Cronbach alphas are all shown to be greater than 0.70 cutoff recommended by Nunnally (1978), showing that construct reliability is present in our sample.

\subsection{Construct Validity}

Construct validity was examined using factor analytic techniques available through SPSS 20.0, a statistical software package. Objective measures of validity include internal consistency, inter-item correlation, as well as discriminant validity. Fornell and Larcker (1981) suggest that if the average variance extracted (AVE) of the scale is greater than 50 percent, internal validity is present as a greater portion of variance is explained by the scale than by random error. Inter-item correlation examines whether items within a scale are correlated with each other. Worthington and Whittaker (2006) suggest to only retain those items where factor loadings are greater than 0.32 , as these scales are likely not measuring what they are intended to measure. Streiner and Norman (1995) find that items which do not have inter-item correlations greater than 0.20 are likely measuring a different construct from the rest of the items. This cutoff ensures that items which remain are highly correlated with each other as uncorrelated items could suggest an attenuation of scale validity.

In addition, Table 2 reports the pair-wise correlations between latent factor scores and the square root of average variance extracted along the diagonal. This is done to test for discriminant validity as suggested by Fornell and Larcker(1981). Discriminant validity is shown as the square root of average variance extracted is higher than all the pair-wise correlations. Therefore, discriminant validity is shown, and multi-collinearity does not seem to pose any significant problems within our sample.

Insert Table 2 here

\section{Results}

Using SPSS 20.0, retained measurement items from Appendix A were used to develop factor scores that were subsequently used in the analysis. Specifically, the retained factor scores were used as variables in the ordinary least squares (OLS) regressions conducted to test the hypotheses presented earlier. Several models are tested to assess the performance implications of a market orientation and its component development within various value disciplines. Market orientation is measured as the sum of the factor scores for customer orientation, competitor orientation and interfunctional coordination. Relative emphasis is measured as the ratio of customer orientation to competitor orientation. First, the model is tested using the entire sample of 269 cow-calf firms, while subsequent models are tested using firms operating within different value discipline strategies. Firm performance within each value discipline strategy is modeled in the following manner.

Performance $=f$ (Market orientation, Relative customer orientation, Innovation, Organizational learning, Cost focus, Size, Experience, Age)

Using a scale developed by Authors (2009) firms were placed into a customer intimacy, operational excellence, or mixed value discipline strategy. Placement was dependent on their average score for the value discipline scale. 
Firms with an average of 50.0 or greater for the customer intimacy (operational excellence) statements were categorized as customer intimacy (operational excellence) producers. Producers that did not meet either of these criteria were placed in the mixed value discipline strategy category.

Standard OLS regressions were used to measure the impact independent variables had on subjective performance. The effects of a market orientation, relative emphasis, innovation, and organizational learning were examined using a sequence of OLS regression models (Table 3). Results indicate that a market orientation is an important determinant of firm performance, while the importance of other variables changes depending on the choice of value discipline strategy.

\section{Insert Table 3 here}

As shown in Table 3, within the full sample of 269 cow-calf producers, a market orientation (H1a supported: $\mathrm{b}=$ $0.162, \mathrm{p}<0.01$ ), innovation (H5 supported: $\mathrm{b}=0.137, \mathrm{p}<0.05$ ), and producer age $(\mathrm{b}=0.001, \mathrm{p}<0.10)$ positively contribute to firm performance. These results are similar to previous findings (Han et al., 1998). It seems that within the cow-calf sector of the Illinois beef industry, a market orientation and innovativeness are important managerial resources which can be developed and subsequently deployed to improve firm performance. Interestingly, producer age, not experience in the beef industry, was shown to lead to improved performance. This may be due to the fact that as producers age, they become more risk averse and thus develop management strategies with a more narrow range of performance, but a higher likelihood of success.

Within the customer intimacy sub-sample, a market orientation is again shown to lead to increased firm performance (H1b supported: $b=0.201, p<0.01$ ). An emphasis on developing a customer orientation was not shown to lead to improved performance (H2 not supported), which corroborates the findings of Slater and Narver (1994), and is contrary to the findings of Tajeddini (2010). Similarly, within the operational excellence sub-sample, a market orientation is the only significant contributor to firm performance (H1c supported: $b=1.67$, $\mathrm{p}<0.01)$. Within the operational excellence strategy, the relative emphasis was not shown to contribute significantly to firm performance (H3 not supported). Further, a focus on costs was also not shown to contribute to improved performance (H6 not supported).

For firms operating with a mixed value discipline strategy, a market orientation was not shown to contribute to firm performance, which is contrary to earlier findings (Johnson et al., 2009; Narver \& Slater, 1990). Interestingly, an increase in herd size actually led to a decrease in firm performance $(b=-0.005, p<0.05)$. This result does not corroborate previous results from the agricultural economics literature (Ramsey et al., 2005). These contrary findings may be driven more so by the mixed value discipline strategy than by a lack of economies of scale. If firms are not able to clearly define how they provide value for downstream channel partners, an increase in herd size may not be the appropriate strategic response. In situations such as these, firms that are unable to focus on one singular value discipline and are therefore unable to efficiently develop the appropriate resources and capabilities, are going to find it difficult to improve performance simply by increasing herd size.

In general, our results indicate that a market orientation and innovation are important determinants of firm performance in this sample of Illinois beef producers. These important results corroborate and clarify earlier studies which examined the relationship between market orientation and performance within food and agriculture settings (Slater \& Narver, 1994; Tregear, 2003; Verhees \& Meulenberg, 2004). When examining these relationships within separate value disciplines, we find a customer focus to not be important in terms of its impact on profitability. This result corroborates the findings of Slater and Narver (1994) who find that a market orientation is an important resource in any environment.

\section{Conclusions}

\subsection{Managerial Implications}

The purpose of this research was to examine the importance of a market orientation and the relative emphasis of a customer orientation across various value discipline strategies within the Illinois beef industry. Overall, our findings support previous research which found that a market orientation and innovativeness contributed to firm performance (Han et al., 1998; Slater \& Narver, 1995). We were not able to find evidence to suggest that the relative emphasis on a customer or competitor orientation was an important determinant of firm performance.

These findings are important as an increasing number of innovative and entrepreneurial agricultural firms are operating outside of the traditional commodity framework. Within such markets, a market orientation is a powerful resource as it enables the firm to become aware of opportunities to provide superior value for consumers. These findings further show that within different value disciplines, the specific manner by which 
resources are allocated in the development of the market orientation is important. These results are similar to the findings of Slater and Narver (1994) who suggest that continually changing the relative emphasis of customer versus competitor orientation may not be prudent given the time and financial resources used in the development of a market orientation. That is, the development of a market orientation or customer orientation is not instantaneous so by the time the orientation is adjusted to the competitive environment, the conditions may have already changed.

While the results of Tajeddini (2010) suggest that the relative emphasis on the components of a market orientation is important, those results were found using Swiss hotel data. It may be that the Illinois beef industry is more comparable to SBUs of a forest products firm (Slater \& Narver, 1994) than that of Swiss hotels (Tajeddini, 2010). Cow-calf producers often do not sell their production directly to the consumer, which would be drastically different than the situation faced by hotel managers, but may be similar to forest products firms. As firms move closer to the consumer interface, modifying the relative emphasis may be an important strategic decision, but for firms located further upstream in the value chain, a focus on developing a balanced market orientation might be the more prudent decision.

Furthermore, Slater and Narver (1998) suggest that a customer orientation and a market orientation are two vastly different constructs. Firms that focus solely on consumers run the risk of developing competitive blind spots as they are focusing only on the needs of current expressed needs of consumers and not scanning the competitive landscape to determine consumers' underlying latent needs. By focusing only on current consumers (or current competitors) firms may turn the core competencies of market awareness and responsiveness into core rigidities (Leonard-Barton, 1992).

\subsection{Limitations and Future Research}

While our results point to some interesting implications for agricultural managers, the nature of our sample may limit the ability to generalize the results. Our sample focused on the Illinois beef industry, so further research could examine these results across beef producing areas and across both crops and livestock producers. Further, the use of cross sectional data only allows us to see that the variables are related, not necessarily the direction of causation. Finally, the use of subjective performance limits the ability to interpret the results. Future research could use panel data to overcome some of these limitations.

Previous findings have shown that a market orientation is an important resource in agricultural markets (Grunert et al., 2005; Johnson et al., 2009). This research study found a market orientation to be an important determinant of firm performance across value discipline strategies in the Illinois cow-calf sector. Future research could examine the relationships between market orientation, relative emphasis, and innovation across crops and livestock and across cultures to clarify these results. Also, other variables could be incorporated into future models to account for channel trust and commitment as well as perceived environmental turbulence. As channel choices for agricultural and other producers continue to expand, further research is needed to determine the appropriate managerial responses for each strategic choice.

\section{References}

Armstrong, J. S., \& Overton, T. S. (1977). Estimating Nonresponse Bias in Mail Surveys. Journal of Marketing Research, 14(3), 396-402. http://dx.doi.org/10.2307/3150783

Baker, W. E., \& Sinkula, J. M. (1999). The Synergistic Effect of Market Orientation and Learning Orientation on Organizational Performance. Journal of the Academy of Marketing Science, 27(4), 411-427. http://dx.doi.org/10.1177/0092070399274002

Bigne, E., \& Blesa, A. (2003). Market orientation, trust and satisfaction in dyadic relationships: a manufacturer-retailer analysis. International Journal of Retail \& Distribution Management, 31(11), 574-590. http://dx.doi.org/10.1108/09590550310503302

Darroch, J., \& McNaughton, R. (2003). Beyond market orientation: Knowledge management and the innovativeness of New Zealand firms. European Journal of Marketing, 37(3/4), 572-593. http://dx.doi.org/10.1108/03090560310459096

Day, G. S., \& Wensley, R. (1988). Assessing Advantage: A Framework for Diagnosing Competitive Superiority. Journal of Marketing, 52(2), 1-20. http://dx.doi.org/10.2307/1251261

Deshpandé, R., Farley, J. U., Frederick, E., \& Webster, J. (1993). Corporate Culture, Customer Orientation, and Innovativeness in Japanese Firms: A Quadrad Analysis. Journal of Marketing, 57(1), 23-37. http://dx.doi.org/10.2307/1252055 
Dev, C., Zhou, K. Z., Brown, J., \& Agarwal, S. (2009). Customer Orientation or Competitor Orientation: Which Marketing Strategy Has a Higher Payoff for Hotel Brands? Cornell Hospitality Quarterly, 50(1), 19-28. http://dx.doi.org/10.1177/1938965508320575

Farrell, M. A., \& Oczkowski, E. (2002). Are Market Orientation and Learning Orientation Necessary for Superior Organizational Performance? Journal of Market-Focused Management, 5(3), 197-217. http://dx.doi.org/10.1023/A:1022990622706

Featherstone, A. M., Langemeier, M. R., \& Ismet, M. (1997). A Nonparametric Analysis of Efficiency for a Sample of Kansas Beef Cow Farms. Journal of Agricultural and Applied Economics, 29(1), 175-184.

Fornell, C., \& Larcker, D. F. (1981). Evaluating Structural Equation Models with Unobservable Variables and Measurement Error. Journal of Marketing Research, 18(1), 39-50. http://dx.doi.org/10.2307/3151312

Gatignon, H., \& Xuereb, J.-M. (1997). Strategic Orientation of the firm and New Product Performance. Journal of Marketing Research, 34(1), 77-90. http://dx.doi.org/10.2307/3152066

Greenley, G. E. (1995). Market Orientation and Company Performance: Empirical Evidence From UK Companies. British Journal of Management, 6(1), 1-13. http://dx.doi.org/10.1111/j.1467-8551.1995.tb00082.x

Grunert, K. G., Jeppesen, L. F., Jespersen, K. R., Sonne, A.-M., Hansen, K., Trondson, T., \& Young, J. A. (2005). Market orientation of value chains: A conceptual framework based on four case studies from the food industry. European Journal of Marketing, 39(5/6), 428-455. http://dx.doi.org/10.1108/03090560510590656

Han, J. K., Kim, N., \& Srivastava, R. K. (1998). Market Orientation and Organizational Performance: Is Innovation a Missing Link? Journal of Marketing, 62(4), 30-35. http://dx.doi.org/10.2307/1252285

Hinson, R. E., \& Abdulai, M. (2011). Qualitative Insights into Market Orientation in Small Ghanaian Businesses. International Journal of Marketing Studies, 3(1), 35-44.

Homburg, C., Workman, Jr., J. P., \& Krohmer, H. (1999). Marketing's Influence within the Firm. Journal of Marketing, 63(2), 1-17. http://dx.doi.org/10.2307/1251942

Hult, G. T. M., \& Ketchen, Jr., D. J. (2001). Does Market Orientation Matter?: A Test of the Relationship Between Positional Advantage and Performance. Strategic Management Journal, 22(9), 899-906. http://dx.doi.org/10.1002/smj.197

Hurley, R. F., \& Hult, G. T. M. (1998). Innovation, Market Orientation, and Organizational Learning: An Integration and Empirical Examination. Journal of Marketing, 62(3), 42-54. http://dx.doi.org/10.2307/1251742

Jaworski, B. J., \& Kohli, A. K. (1993). Market Orientation: Antecedents and Consequences. Journal of Marketing, 57(3), 53. http://dx.doi.org/10.2307/1251854

Johnson, A. J., Dibrell, C. C., \& Hansen, E. (2009). Market Orientation, Innovativeness, and Performance of Food Companies. Journal of Agribusiness, 27(1/2), 85-106.

Jones, R. (2000). Costs, Distribution of Costs, and Factors Influencing Profitability in Cow-Calf Production. Research Bulletin 3-2000. Blacksburg, VA: Research Institute on Livestock Pricing. [Online] Available: http://naiber.org/Publications/RILP/cowcalf.pdf

Kim, W. C., \& Mauborgne, R. (2004). Blue ocean strategy. Harvard Business Review, 82(10), 76-84. Harvard Business School Publishing. [Online] Available: http://www.ncbi.nlm.nih.gov/pubmed/16669322

Kotha, S., \& Vadlamani, B. L. (1995). Assessing Generic Strategies: An Empirical Investigation of Two Competing Typologies in Discrete Manufacturing Industries. Strategic Management Journal, 16(1), 75-83. http://dx.doi.org/10.1002/smj.4250160108

Lamb, R. L., \& Beshear, M. (1998). From the Plains to the Plate: Can the Beef Industry Regain Market Share? Economic Review - Federal Reserve Bank of Kansas City, 48(3), 49-66.

Leonard-Barton, D. (1992). Core capabilities and core rigidities: A paradox in managing new product development. Strategic Management Journal, 13(S1), 111-125. http://dx.doi.org/10.1002/smj.4250131009

Lukas, B. A., \& Ferrell, O. C. (2000). The effect of market orientation on product innovation. Academy of Marketing Science, 28(2), 239-247. http://dx.doi.org/10.1177/0092070300282005

Micheels, E. T., \& Gow, H. R. (2009). Do Market Oriented Firms Demonstrate Clarity on Their Value Discipline? Evidence from Illinois Beef Producers. International Food and Agribusiness Management Review, 12(3), 127-152. 
Mokhtar, S. S. M., Yusoff, R. Z., \& Arshad, R. (2009). Market Orientation Critical Success Factors of Malaysian Manufacturers and Its Impact on Financial Performance. International Journal of Marketing Studies, 1(1), 77-84.

Narver, J. C., \& Slater, S. F. (1990). The Effect of a Market Orientation on Business Profitability. Journal of Marketing, 54(4), 20-35. http://dx.doi.org/10.2307/1251757

Narver, J. C., Slater, S. F., \& Tietje, B. (1998). Creating a Market Orientation. Journal of Market Focused Management, 2(3), 241-255. http://dx.doi.org/10.1023/A:1009703717144

Nunnally, J. C. (1978). Psychometric theory. New York: McGraw-Hill.

Pelham, A. M. (1997). Mediating Influences on the Relationship between Market Orientation and Profitability in Small Industrial Firms. Journal of Marketing Theory and Practice, 5(3), 55-76.

Pelham, A. M. (1999). Influence of Environment, Strategy, and Market Orientation on Performance in Small Manufacturing Firms. Journal of Business Research, 45(1), 33-46. http://dx.doi.org/10.1016/S0148-2963(98)00026-5

Peteraf, M. A. (1993). The Cornerstones of Competitive Advantage: A Resource-Based View. Strategic Management Journal, 14(3), 179-191. http://dx.doi.org/10.1002/smj.4250140303

Porter, M. E. (1985). Competitive Advantage: Creating and Sustaining Superior Performance. New York: Simon and Schuster.

Porter, M. E. (1991). Towards a Dynamic Theory of Strategy. Strategic Management Journal, 12(S2), 95-117. http://dx.doi.org/10.1002/smj.4250121008

Ramsey, R., Doye, D., Ward, C., McGrann, J., Falconer, L., \& Bevers, S. (2005). Factors Affecting Beef Cow-Herd Costs, Production, and Profits. Journal of Agricultural and Applied Economics, 37(1), 91-99.

Schumacher, S., \& Boland, M. (2005). The Effects of Industry and Firm Resources on Profitability in the Food Economy. Agribusiness, 21(1), 97-108. http://dx.doi.org/10.1002/agr.20033

Slater, S. F., \& Narver, J. C. (1994). Does Competitive Environment Moderate the Market Orientation-Performance Relationship? Journal of Marketing, 58(1), 46-55. http://dx.doi.org/10.2307/1252250

Slater, S. F., \& Narver, J. C. (1995). Market Orientation and the Learning Organization. Journal of Marketing, 59(3), 63-74. http://dx.doi.org/10.2307/1252120

Slater, S. F., \& Narver, J. C. (1998). Customer-Led and Market-Oriented: Let's Not Confuse the Two. Strategic Management Journal, 19(10), 1001-1006. http://dx.doi.org/10.1002/(SICI)1097-0266(199810)19:10<1001::AID-SMJ996>3.0.CO;2-4

Streiner, D. L., \& Norman, G. R. (1995). Health measurement scales: a practical guide to their development and use (2nd ed.). New York: Oxford University Press.

Tajeddini, K. (2010). Effect of customer orientation and entrepreneurial orientation on innovativeness: Evidence from the hotel industry in Switzerland. Tourism Management, 31(2), 221-231. Elsevier Ltd. http://dx.doi.org/10.1016/j.tourman.2009.02.013

Teece, D. J., Pisano, G., \& Shuen, A. (1997). Dynamic Capabilities and Strategic Management. Strategic Management Journal, 18(7), 509-533. http://dx.doi.org/10.1002/(SICI)1097-0266(199708)18:7<509::AID-SMJ882>3.0.CO;2-Z

Treacy, M., \& Wiersema, F. (1993). Customer Intimacy and Other Value Disciplines. Harvard Business Review, 71(1), 84-93.

Tregear, A. (2003). Market orientation and the craftsperson. European Journal of Marketing, 37(11/12), 1621-1635. http://dx.doi.org/10.1108/03090560310495384

Verhees, F. J. H. M., \& Meulenberg, M. T. G. (2004). Market Orientation, Innovativeness, Product Innovation, and Performance in Small Firms. Journal of Small Business Management, 42(2), 134-154. http://dx.doi.org/10.1111/j.1540-627X.2004.00102.x

Worthington, R. L., \& Whittaker, T. a. (2006). Scale Development Research: A Content Analysis and Recommendations for Best Practices. The Counseling Psychologist, 34(6), 806-838. http://dx.doi.org/10.1177/0011000006288127 


\section{Notes}

Note 1. The operational excellence value discipline is similar to the cost leadership strategy of Porter (1985) and is the dominant strategy in commodity markets such as agriculture. As producers are generally unable to affect the price they receive, increasing efficiency is seen as the only method to earn higher profits in this market. Customer intimacy and product leadership would seem to fall into the differentiation strategy of Porter (1985) with a customer intimacy value discipline focusing on providing the exact product to meet a specific customer's needs. A product leadership value discipline searches for sources of product innovations and markets them quickly to become the first-mover in the market.

Note 2. In surveys where only a few responses were missing, responses were imputed through a regression. This method attenuated the loss of sample size that would otherwise occur had listwise deletion been employed.

Note 3. See Micheels and Gow (2009) for a discussion of scale development and reliability estimates of the value discipline scale.

Table 1. Characteristics of Illinois cow-calf producers $(n=269)$

\begin{tabular}{|c|c|c|}
\hline Characteristics & Frequency & Relative Frequency (\%) \\
\hline \multicolumn{3}{|l|}{ Age $^{a}$} \\
\hline Under 30 & 9 & 3.3 \\
\hline $31-40$ & 21 & 7.8 \\
\hline $41-50$ & 67 & 24.9 \\
\hline $51-60$ & 96 & 35.7 \\
\hline Over 60 & 74 & 27.5 \\
\hline \multicolumn{3}{|l|}{ Experience } \\
\hline Less than 10 years & 30 & 11.2 \\
\hline 11-15 & 23 & 8.6 \\
\hline $16-20$ & 21 & 7.8 \\
\hline 21-25 & 17 & 6.7 \\
\hline More than 25 years & 177 & 65.8 \\
\hline \multicolumn{3}{|l|}{ Education } \\
\hline Some High School & 2 & 0.7 \\
\hline High School graduate & 60 & 22.3 \\
\hline Some College & 48 & 17.8 \\
\hline Technical College graduate & 34 & 12.6 \\
\hline College graduate & 107 & 39.8 \\
\hline Post-graduate degree & 18 & 6.7 \\
\hline \multicolumn{3}{|l|}{ Size of herd } \\
\hline Fewer than 30 head & 96 & 35.7 \\
\hline 31-75 head & 99 & 36.8 \\
\hline 76-150 head & 44 & 16.4 \\
\hline Greater than 150 head & 30 & 11.2 \\
\hline
\end{tabular}

Note: ${ }^{a}$ For Age, $n=267$ as two respondents did not complete this portion of the questionnaire. 
Table 2. Correlations among latent and observed variables

\begin{tabular}{|l|c|c|c|c|c|c|c|c|c|}
\hline Construct/Variable & $\mathbf{1}$ & $\mathbf{2}$ & $\mathbf{3}$ & $\mathbf{4}$ & $\mathbf{5}$ & $\mathbf{6}$ & $\mathbf{7}$ & $\mathbf{8}$ & $\mathbf{9}$ \\
\hline 1. Market Orientation & $\mathbf{0 . 7 2 4}$ & & & & & & & \\
\hline 2. Innovativeness & 0.162 & $\mathbf{0 . 8 5 1}$ & & & & & & \\
\hline $\begin{array}{l}\text { 3. Organizational } \\
\text { Learning }\end{array}$ & 0.325 & 0.427 & $\mathbf{0 . 7 2 9}$ & & & & & & \\
\hline 4. Cost Focus & 0.326 & 0.455 & 0.403 & $\mathbf{0 . 7 1 4}$ & & & & & \\
\hline 5. Performance & 0.346 & 0.217 & 0.244 & 0.198 & $\mathbf{0 . 8 3 1}$ & & & & \\
\hline 6. Relative emphasis & -0.045 & 0001 & -0.176 & -0.056 & -0.055 & & & & \\
\hline 7. Firm size (herd size) & 0.146 & 0083 & 0.064 & 0.196 & -0.019 & 0.065 & & & \\
\hline 8. Experience & 0.078 & -0.093 & -0.145 & 0.104 & 0.052 & 0.076 & 0.049 & & \\
\hline 9. Age & 0.032 & 0.017 & 0.053 & 0.085 & 0.119 & -0.014 & -0.011 & 0.000 & \\
\hline
\end{tabular}

Note: Diagonal shows square root of variance extracted for latent variables.

Table 3. Regression results

\begin{tabular}{|l|c|c|c|c|c|c|c|c|}
\hline & \multicolumn{2}{|c|}{$\begin{array}{c}\text { Full Sample } \\
\text { (n=269) }\end{array}$} & $\begin{array}{r}\text { Customer Intimacy } \\
\text { (n=82) }\end{array}$ & \multicolumn{2}{c|}{$\begin{array}{c}\text { Operational } \\
\text { Excellence (n=86) }\end{array}$} & \multicolumn{2}{c|}{$\begin{array}{c}\text { Mixed Strategy } \\
\text { (n 102) }\end{array}$} \\
\hline & Coefficient & t-value & Coefficient & t-value & Coefficient & t-value & Coefficient & t-value \\
\hline Intercept & -0.15 & -0.62 & -0.77 & -1.00 & -1.59 & -1.55 & 0.65 & 0.16 \\
\hline $\begin{array}{l}\text { Market } \\
\text { orientation }\end{array}$ & $0.162 * * *$ & 4.80 & $0.201 * * *$ & 2.94 & $1.67 * * *$ & 2.68 & 0.70 & 1.01 \\
\hline Relative & & & & & & & & 0.00 \\
emphasis & 0.00 & -0.40 & -0.08 & -1.07 & 0.21 & 0.60 & -0.31 \\
\hline Innovativeness & $0.137 * *$ & 2.00 & 0.12 & 1.16 & 0.15 & 1.03 & 0.04 & 0.29 \\
\hline $\begin{array}{l}\text { Organizational } \\
\text { learning }\end{array}$ & 0.15 & 1.27 & 0.15 & 0.70 & 0.09 & 0.37 & 0.18 & 1.01 \\
\hline Cost focus & 0.00 & 0.05 & -0.07 & -0.60 & 0.07 & 0.50 & 0.10 & 0.79 \\
\hline Herd size & 0.00 & -1.38 & 0.00 & -0.27 & 0.00 & 0.16 & $-0.005 * *$ & -2.05 \\
\hline Experience & 0.01 & 1.01 & -0.01 & -0.62 & 0.00 & 0.06 & 0.01 & 0.52 \\
\hline Age & $0.001 *$ & 1.78 & 0.02 & 1.39 & 0.03 & 1.29 & 0.00 & 1.62 \\
\hline F & 6.573 & & 2.644 & & 0.803 & & 1.938 & \\
\hline Adjusted R & 0.144 & & 0.140 & & 0.070 & & 0.070 & \\
\hline
\end{tabular}

Note: Asterisks indicate level of significance. $* * *, * *$, and $*$ indicate significance at $\mathrm{p}<0.001, \mathrm{p}<0.05$, and $\mathrm{p}<$ 0.10 levels respectively. 
Appendix A. Scale reliability and validity

\begin{tabular}{|c|c|c|c|}
\hline & Alpha & $\begin{array}{l}\text { Variance } \\
\text { Extracted }\end{array}$ & $\begin{array}{l}\text { Item-to-total } \\
\text { correlation }\end{array}$ \\
\hline Customer Orientation & 0.762 & $57.63 \%$ & \\
\hline $\begin{array}{l}\text { We continuously try to discover additional needs of our customers of } \\
\text { which they are unaware. }\end{array}$ & & & 0.634 \\
\hline $\begin{array}{l}\text { We incorporate solutions to unarticulated customer needs in our new } \\
\text { products and services. }\end{array}$ & & & 0.614 \\
\hline $\begin{array}{l}\text { We innovate even at the risk of making our previous farming } \\
\text { practices obsolete. }\end{array}$ & & & 0.332 \\
\hline $\begin{array}{l}\text { We work closely with lead customers to try to recognize their needs } \\
\text { months or even years before the majority of the market may } \\
\text { recognize them. }\end{array}$ & & & 0.580 \\
\hline Competitor Orientation & 0.865 & $52.44 \%$ & \\
\hline $\begin{array}{l}\text { Employees on our farm share information concerning competitor's } \\
\text { activities. }\end{array}$ & & & 0.536 \\
\hline We regularly discuss competitor's strengths and weaknesses. & & & 0.543 \\
\hline $\begin{array}{l}\text { We target customers where we have an opportunity for competitive } \\
\text { advantage. }\end{array}$ & & & 0.494 \\
\hline $\begin{array}{l}\text { Members of our farm collect information concerning competitor's } \\
\text { activities. }\end{array}$ & & & 0.643 \\
\hline We diagnose competitor's goals. & & & 0.699 \\
\hline $\begin{array}{l}\text { We identify the areas where key competitors have succeeded or } \\
\text { failed. }\end{array}$ & & & 0.633 \\
\hline We evaluate the strengths and weaknesses of key competitors. & & & 0.679 \\
\hline Interfunctional Coordination & 0.758 & $57.57 \%$ & \\
\hline We regularly visit our current and prospective customers. & & & 0.503 \\
\hline $\begin{array}{l}\text { We freely discuss our successful and unsuccessful customer } \\
\text { experiences with our partners. }\end{array}$ & & & 0.509 \\
\hline $\begin{array}{l}\text { All of our business units (marketing, production, research, finance, } \\
\text { and accounting) are integrated in serving the needs of our target } \\
\text { markets. }\end{array}$ & & & 0.616 \\
\hline $\begin{array}{l}\text { People on our farm understand how everyone can contribute to } \\
\text { creating customer value. }\end{array}$ & & & 0.557 \\
\hline Organizational Learning & 0.778 & $53.15 \%$ & \\
\hline $\begin{array}{l}\text { The basic values of this farm include learning as a key to } \\
\text { improvement. }\end{array}$ & & & 0.596 \\
\hline Our take is that learning is an investment, not an expense. & & & 0.653 \\
\hline $\begin{array}{l}\text { Learning on my farm is seen as a key commodity necessary to } \\
\text { guarantee survival. }\end{array}$ & & & 0.661 \\
\hline $\begin{array}{l}\text { There is little commonality of purpose in my farm/marketing } \\
\text { channel.* }\end{array}$ & & & 0.452 \\
\hline
\end{tabular}




\begin{tabular}{|c|c|c|c|}
\hline $\begin{array}{l}\text { Personnel on this farm realize that the very way they perceive the } \\
\text { marketplace must be continually questioned and adapted. }\end{array}$ & & & 0.339 \\
\hline Innovativeness & 0.747 & $72.43 \%$ & \\
\hline Technical innovation based on research results is readily accepted. & & & 0.480 \\
\hline $\begin{array}{l}\text { We seldom seek innovative ideas which we can use in our cattle } \\
\text { operation.* }\end{array}$ & & & 0.565 \\
\hline Innovation is readily accepted on our beef operation. & & & 0.554 \\
\hline Individuals are penalized for new ideas that don't work. & & & 0.342 \\
\hline Innovation on our farm is perceived as too risky and is resisted.* & & & 0.567 \\
\hline Cost Focus & 0.734 & $50.99 \%$ & \\
\hline Improving the operating efficiency of the business is a top priority. & & & 0.653 \\
\hline We have a continuing goal to lower operating costs. & & & 0.581 \\
\hline $\begin{array}{l}\text { We hardly ever seek to improve production practices so that we can } \\
\text { lower costs.* }\end{array}$ & & & 0.389 \\
\hline $\begin{array}{l}\text { Achievement of economies of scale or scope is an important element } \\
\text { of our strategy. }\end{array}$ & & & 0.333 \\
\hline We closely monitor the effectiveness of key production practices. & & & 0.573 \\
\hline Overall firm performance & 0.832 & $68.98 \%$ & \\
\hline The return on farm assets did not meet expectations last year.* & & & 0.637 \\
\hline $\begin{array}{l}\text { We were very satisfied with the overall performance of the farm last } \\
\text { year. }\end{array}$ & & & 0.688 \\
\hline The return on production investments met expectations last year. & & & 0.753 \\
\hline The cash flow situation of the farm was not satisfactory.* & & & 0.553 \\
\hline The return on marketing investments met expectations last year. & & & 0.657 \\
\hline $\begin{array}{l}\text { The prices we receive for our product is higher than that of our } \\
\text { competitors. }\end{array}$ & & & 0.285 \\
\hline $\begin{array}{l}\text { The overall performance of the farm last year exceeded that of our } \\
\text { major competitors. }\end{array}$ & & & 0.524 \\
\hline
\end{tabular}

